\title{
EFFECT OF RED CABBAGE JUICE AS A HEPATOPROTECTOR ON LIVER ENZYME LEVELS
}

\author{
Efek Jus Kubis Merah sebagai Hepatoprotektor pada Kadar Enzim Hati
}

\author{
Andina Putri Aulia' \\ Hesty Wahyuningsih ${ }^{2}$ \\ ' Department of Pathology Clinic, \\ Faculty of Medicine, UNISSULA, \\ Semarang \\ ${ }^{2}$ Department of Biochemistry, \\ Faculty of Medicine, UNISSULA, \\ Semarang \\ *email: auliaputri.dr@unissula.ac.id
}

\begin{abstract}
Abstrak
Pendahuluan: Antosianin pada kubis merah dikteahui dapat menurunkan kadar enzim hati seperti SGPT, SGOT, ALP dan GGT pada kasus hepatitis akibat induksi obat (DILI). Tujuan: Penelitian ini bertujuan untuk mengetahui efek jus kubis merah terhadap kadar enzim hati tikus galur wistar yang diinduksi asetaminofen

Metode: Penelitian eksperimental dengan rancangan post test only control group design ini menggunakan tikus jantan galur wistar 300 gram yang dibagi menjadi 5 kelompok secara random. KI merupakan kontrol negatif. K2 (kontrol positif), K3, K4 dan K5 diberi asetaminofen $300 \mathrm{mg}$ sebanyak 2 kali dalam 16 jam pada hari pertama. $\mathrm{K} 3, \mathrm{~K} 4$ dan $\mathrm{K} 5$ diberi jus kubis merah secara berturut-turut dengan dosis $0,5 \mathrm{~g} / \mathrm{ml}, 0,7 \mathrm{~g} / \mathrm{ml}$ dan $0,9 \mathrm{ml}$. Data di analisis dengan uji one way anova dan uji post hoc LSD $(p<0,05)$

Hasil: Tidak ada perbedaan signifikan antar kelompok pada kadar SGOT dan GGT dengan $p=0,271(p>0,05)$ dan $p=0,053(p>0,05)$. Sedangkan pada kadar ALP terdapat perbedaan yang signnifikan antar kelompok dengan $p=0,000$. Kesimpulan: Pemberian jus kubis merah dengan berbagai dosis tidak memiliki efek terhadap kadar SGOT dan GGT pada tikus galur wistar yang diinduksi asetaminofen akan tetapi pemberian jus kubis merah memiliki efek terhadap kadar ALP pada tikus yang diinduksi asetaminofen dengan dosis yang paling efektif adalah $0,5 \mathrm{~g} / \mathrm{ml}$.
\end{abstract}

Kata Kunci:

kubis merah, asetminofen, SGOT, $A L P, G G T$

\section{Keywords:}

red cabbage, acetaminophen, SGOT, $A L P, G G T$

\begin{abstract}
Background: Anthocyanin-rich red cabbage is known to reduce hepatic enzymes levels such as SGPT, SGOT, ALP and GGT in drug induced liver injury (DILI). Objective: This study aimed to determine the effect of red cabbage juice on SGOT, ALP and GGT levels in acetaminophen induced liver injury in rats.

Methods: This was an experimental study using post test only control group design. Thirty male wistar rats were randomly divided into 5 groups. $K I$ was the negative control. K2, K3, K4 and K5 were pretreated with $300 \mathrm{mg}$ acetaminophen. K3, K4 and $K 5$ were treated with $0.5 \mathrm{~g} / \mathrm{ml}$ of red cabbage juice, $0.7 \mathrm{~g} / \mathrm{ml}$ of red cabbage juice and $0.9 \mathrm{~g} / \mathrm{ml}$ of red cabbage juice respectively. Data were analyzed using one way anova.and post hoc LSD $(p<0.05)$.

Results: There was no significant difference of SGOT and GGT levels among the groups $p=0.27 I(p>0.05)$ and $p=0.053(p>0.05)$ respectively. Whereas ALP levels showed significant difference among the groups $p=0.000(p<0,05)$ respectively. Conclusion: The administration of red cabbage in any dose had no effect on SGOT and GGT levels in acetaminophen induced liver injury in rats whereas in ALP, the most effective dose to cause an effect is $0.5 \mathrm{~g} / \mathrm{ml}$.
\end{abstract}

\section{INTRODUCTION}

Cabbage has plentiful nutrients that beneficial for the body, especially flavonoids. Two types of cabbage often used in society, namely white and red cabbage. Red cabbage has more flavonoid content than cabbage. The flavonoid contained in red cabbage is anthocyanin. Anthocyanins can act as anti-inflammatory, antioxidant, and anti-allergic agents. Therefore, red cabbage has long been used by people in the world as traditional medicines (Rokayya et al., 20I3). Lately, red cabbage has known as a hepatoprotection. Druginduced liver injury (DILI) is an acute and chronic liver disease caused by the use of drugs that exceed the recommended dose. The incidence of DILI in Indonesia 
is an iceberg phenomenon that can increase morbidity and mortality rates. The role of the hepatoprotective effect of red cabbage in DILI cases is still limited. The use of red cabbage in extract form is quite difficult to be applied in the community, hence the use of red cabbage juice needs to be considered. Not only is it easy to use, but the use of juice can also increase the effects of anthocyanin (Zeitschrift, 2014). However, research on the potency of the hepatoprotective effect of red cabbage juice on DILI cases is still lacking.

The liver is one of the organs in the body that has a significant role in the body's metabolism of various substances and detoxification. The liver can experience anatomic, physiological, and histological disorders caused by the inflammatory process and oxidative stress that occur in liver cells, one of the causes is due to the exposure to toxic substances such as drugs. Liver disorders due to the induction of hepatotoxic drugs are called Drug-Induced Liver Injury (DILI). The diagnosis of DILI can be made by increasing levels of glutamic pyruvic transaminase serum and glutamic oxaloacetic transaminase serum by more than three times the normal limit valuations (Harrison, 2010). One of the hepatotoxic drugs is acetaminophen. Acetaminophen is an antipyretic and analgesic drug group whose use is still relatively high. The incidence of liver failure due to drug induction in the United States reaches $50 \%$ and $39 \%$ of them are caused by acetaminophen. The National Agency for Drug and Food Control (BPOM) recorded DILI cases in Indonesia in 2002-2005 as many as I7I cases of DILI due to the induction of acetaminophen out of 201 DILI cases as a whole. The usage of potentially hepatotoxic drugs in Indonesia has recently become a trend in some regions. In Tasikmalaya, up to $96 \%$ of people use potentially hepatotoxic drugs, one of which is acetaminophen. While in Bandung there are $80.4 \%$ of drug users who used potentially hepatotoxic and the most widely used is acetaminophen (Cahaya and Mutia, 2014). In Indonesia, DILI is an iceberg phenomenon. The grounds for this are the data collection of cases is still incomplete, the lack of regulation and compliance with guiding the drug allows the number of patients with DILI due to the induction of acetaminophen is bigger than the data collection, so that it will increase morbidity and mortality. Therefore, further research is needed to reduce morbidity and mortality due to DILI.

Acetaminophen in high doses can be toxic to cells by a metabolite called $\mathrm{N}$-acetyl benzoquinone imine (NAPQI) thereby increasing the formation of Reactive Oxygen Species (ROS) that exceed oxidants such as glutathione (GSH) (Chughlay et al., 20I5). Damage to liver cells can be identified through several indicators such as Serum Glutamic Pyruvic Transaminase (SGPT), Serum Glutamic Oxaloacetic Transaminase (SGOT), Alkaline phosphatase (ALP) and gamma-glutamyl transferase (XGT) (Harrison, 2010). This situation can be prevented by balancing the number of antioxidants against the increase in oxidants, one of which is by using anthocyanin which is a potent antioxidant and protects cells from oxidative stress (Horbowicz et al., 2008). This is proven by previous studies of Rosella petals, purple yam, and rice berry as a potent hepatoprotective product characterized by a significant decrease in liver enzymes in the induction of acetaminophen. (Gana Suganda, 2005; Arjinajarn et al., 2017; Wang et al., 2017).

Flavonoids are compounds which synthesized from phenylalanine. One type of flavonoid is anthocyanin. Anthocyanin contains a color pigment that will show purplish-red in some vegetables, one of which is red cabbage (Brassica oleracea var. Capitata I). The content of anthocyanin in red cabbage is quite high at $63.50 \mathrm{mg} / \mathrm{l00g}$ foodstuffs (Kozlowska, 2014; Grande, 20I4). Research conducted by Maha (20I2) proves that the use of $10 \%$ red cabbage powder with or without cysteine can reduce levels of SGPT, SGOT, ALP, GGT and improve the microscopic picture of the liver in white albino rats induced by acetaminophen $2 \mathrm{~g} / \mathrm{kg}$ for 60 days. It is mediated by a decrease in levels of 
oxidative stress and also an increase in glutathione biosynthesis. However, research on the effectiveness of anthocyanins contained in red cabbage juice as an acetaminophen-induced hepatoprotector is still very limited (El-Motaleb el-Moway, 20I2). Therefore, this study wants to prove whether red cabbage juice acts as a hepatoprotector by measuring SGOT, ALP, and GGT levels in liver damage induced by acetaminophen.

\section{METHODS}

This is an experimental research with a posttest control group design. This research has received approval from the Bioethics Commission of the Faculty of Medicine UNISSULA with ethical clearance No.357/IX/2018/Komisi Bioetik. The independent variable in this study was red cabbage juice, the dependent variable was the levels of SGOT, ALP, and GGT. Red cabbage juice is red cabbage leaves that are cut into small pieces and weighed as much as $\mathbf{5 0}$ grams for a dose of $0.5 \mathrm{~g} / \mathrm{ml}, 70$ grams for a dose of $0.7 \mathrm{~g} / \mathrm{ml}$ and 90 grams for a dose of $0.9 \mathrm{~g} / \mathrm{ml}$. Each added $100 \mathrm{ml}$ of distilled water then blended and filtered. Each dose of red cabbage juice was given to mice with a $1.5 \mathrm{ml}$ stomach swab twice a day in the morning and evening. Acetaminophen was given 2 times with a span of 16 hours as much as $3 \mathrm{ml}$ with a dose of $300 \mathrm{mg}$. The SGOT, ALP, and GGT serums were taken from Ophthalmic vein male Wistar rats, taken on day 22. Assessment of serum SGOT, ALP, and GGT levels were carried out using a spectrophotometer.

The test subjects were male Wistar rats kept in the Laboratory of Veterinary Medicine, Diponegoro University, Semarang, which met the inclusion criteria, namely 2-3 months of age, 300 grams of body weight, no anatomical defects, looked healthy, active, had no injuries, ate and drink normally. The study was conducted for 21 days and on the 22nd day, serum was taken through ophthalmic vein to check the levels of SGOT, ALP, and GGT.
Data obtained from the measurement of SGOT, ALP, and GGT levels of all research test subjects. Statistical analysis used the one-way ANOVA test and continued with the Post-Hoc LSD.

\section{RESULTS AND DISCUSSION}

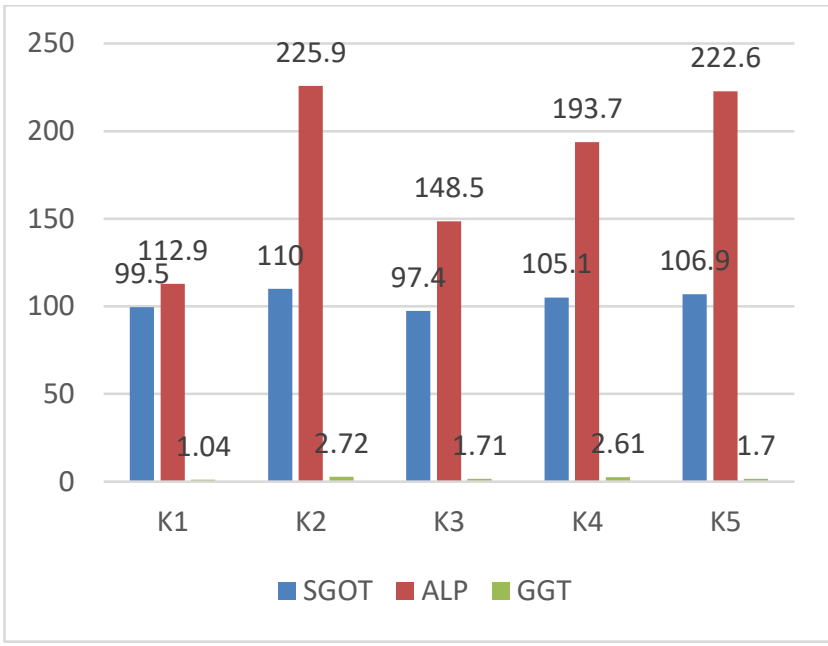

Figure I. The graph of the mean SGOT, ALP and GGT level (IU/L)

Table I. The results of the normality test for Saphiro Wilk and the Levene test

\begin{tabular}{ccccccc}
\hline \multicolumn{2}{c}{ SGOT } & \multicolumn{2}{c}{ ALP } & \multicolumn{2}{c}{ GGT } \\
\hline & $\begin{array}{c}\text { Norm } \\
\text { ality } \\
\text { Test } \\
\text { Result } \\
\text { s }\end{array}$ & $\begin{array}{c}\text { Leyene } \\
\text { 's Test } \\
\text { Results }\end{array}$ & $\begin{array}{c}\text { Normal } \\
\text { ity Test } \\
\text { Results }\end{array}$ & $\begin{array}{c}\text { Leyene' } \\
\text { इ Test } \\
\text { Results }\end{array}$ & $\begin{array}{c}\text { Normal } \\
\text { ity Test } \\
\text { Results }\end{array}$ & $\begin{array}{c}\text { Leyene' } \\
\text { इ Test } \\
\text { Results }\end{array}$ \\
\hline KI & $0.264^{*}$ & $0.054^{*}$ & $0.383^{*}$ & $0.160^{*}$ & 0.42 & 0.36 \\
K2 & $0.106^{*}$ & & $0.065^{*}$ & & 0.295 & \\
K3 & $0.870^{*}$ & & $0.073^{*}$ & & 0.503 & \\
K4 & $0.443^{*}$ & & $0.535^{*}$ & & 0.146 & \\
K5 & $0.593^{*}$ & & $0.077^{*}$ & & 0.935 & \\
\hline
\end{tabular}

* = normal and homogeneous data distribution $(p>$ 0.05)

Table 2. One-way ANOVA hypothesis test

\begin{tabular}{ccc}
\hline $\begin{array}{c}\text { Group } \\
\text { P-value }\end{array}$ & $\begin{array}{c}\text { SGOT } \\
\text { P-value }\end{array}$ & $\begin{array}{c}\text { GGT } \\
\text { P-value }\end{array}$ \\
\hline $0.000^{*}$ & $0.27 \mathrm{I}$ & 0.053 \\
\hline Note: ${ }^{*}=$ significant difference $(\mathrm{P}<0.05)$ \\
The results of the one way ANOVA test in \\
previous study showed that there was an effect of giving \\
red cabbage juice on the levels of & SGPT in
\end{tabular}


acetaminophen-induced rats with $\mathrm{p}$-value 0.000 (Wahyuningsih and Aulia, 2020). This study showed that there was an effect of giving red cabbage juice on the levels of ALP with p-value 0.000. These results are consistent with the research of El-Mowafey el Motaleb (20I2) regarding the effect of anthocyanins in red cabbage extract on levels of SGPT and ALP enzymes in Wistar rats. Red cabbage juice affected reducing ALP levels in Wistar rats, which suggested by a decrease in the mean levels of ALP K2 on K3, respectively. This significant decrease in SGPT and ALP levels is caused by the content of Cyanidine-3-O-glucoside-5-O-glucoside and Cyanidine-3-glucoside in anthocyanins which function to increase GSH and bind ROS so that it can cause a decrease in NAPQI and liver inflammation which is characterized by decreased levels of SGPT and ALP (Wiczkowski et al., 20I3; Wang et al., 2017).

After the LSD post hoc test was carried out in the SGPT (Wahyuningsih and Aulia, 2020) and ALP data groups, it was found that there was a significant difference between $\mathrm{KI}$ and $\mathrm{K} 2$ with $\mathrm{p}<0.005$. There was an increase in SGPT and ALP levels in the acetaminophen-induced group of rats at a dose of 300 $\mathrm{mg}$ with 2 times of administration in 16 hours, clinically. The increase in SGPT and ALP levels is following the research of lyanda and Adeneyi (20II) which states that the administration of these doses can cause mild liver damage. Liver damage due to acetaminophen induction is caused by GSH depletion and an increase in NAPQI metabolites which will result in inflammation and will induce ROS release and cause cellular damage. Hepatocellular damage will induce an increase in SGPT and ALP (Yoon et al., 2016).

Statistically, with the posthoc LSD test on the levels of ALP, there was a significant difference between $K 2$ and $K 3$ with $p=0.001$ and 0.000 ( $p$ 0.05). The comparison between $\mathrm{KI}$ and $\mathrm{K} 3$ at levels of ALP showed a significant difference with $p=0.042$ ( $p$ 0.05). This shows that clinically, red cabbage juice at a dose of $0.5 \mathrm{~g} / \mathrm{ml}$ can reduce ALP levels in acetaminophen- induced liver damage due to the anthocyanin content of red cabbage.

The results of the post hoc LSD test showed that there was a significant difference between $\mathrm{K} 4$ and $\mathrm{K} 5$ against $\mathrm{K} 3$ with $\mathrm{p}=0.000$, while $\mathrm{K} 4$ and $\mathrm{K} 5$ had no significant differences against $K 2$ with $p>0.05$. These data indicate that the ALP levels in the group of mice induced with red cabbage levels of $0.7 \mathrm{~g} / \mathrm{ml}$ and $0.9 \mathrm{~g} / \mathrm{ml}$ are close to the group of rats induced only by acetaminophen. This condition resulting in the higher levels of anthocyanin given, the lower the absorption. The utilization of antioxidants at high doses can also alter the effect of antioxidants into prooxidants and can disrupt the stability of redox reactions in liver cells, thereby increasing levels of ROS. Increased ROS can cause cell mitochondrial dysfunction resulting in cell damage and death (Bohn and Bouayed, 20l0). Based on existing statistical data and theory, it can be concluded that giving red cabbage juice at high doses can cause toxic effects.

Comparison of ALP levels K3, K4, and K5 clinically has the order from the largest to the smallest are $\mathrm{K} 3, \mathrm{~K} 4$, and $\mathrm{K} 5$. This proves that the higher the anthocyanin concentration consumed, the lower the absorption of the anthocyanin components. This is supported by a study by Nielsen et al (2003) regarding the provision of purified black-currant juice with an anthocyanin level of $256 \mathrm{mg} / \mathrm{animal}$ which possesses a lower absorbed cyanidin level compared to animals given anthocyanin with a level of $182 \mathrm{mg} / \mathrm{animal}$.

The one-way ANOVA test resulting in the effect of red cabbage juice on SGOT levels had a value of $p=0.271(p>0.05)$ which stated that there was no significant difference in SGOT levels between the five groups. It is due to there weren't two data groups that had significant differences in the mean SGOT. These results are similar to other studies conducted by Egosha et al (2015) that the provision of Rosella flowers (Hibiscus sabdariffa L.) did not significantly affect SGOT levels ( $p>0.05)$. SGOT is an indicator of hepatocellular 
level liver damage. SGOT production in the liver has high levels, but it is as well produced by other organs such as the heart, kidneys, brain, red blood cells, and skeletal muscles so that AST is less specific as an indicator of hepatotoxicity. SGOT has a half-life of 17 hours so an SGOT level examination that is achieved more than the half-life can lead to insignificant results. Besides, the increase in liver enzymes due to DILI can be determined by the phases of DILI, in which there are four phases. The first phase occurs within the first 24 hours after consuming acetaminophen, the SGOT levels are still normal in this phase. The second phase occurs within 24 hours to 72 hours, in this phase, there is a slight increase in AST levels. The third phase occurs within 72 hours to 96 hours, this is the peak phase of increasing SGOT levels caused by maximum damage to liver cells. The fourth phase occurs after 96 hours, while there has been an improvement in liver cells. This phase can last for I to 2 weeks (Egoshaet al, 2015; Giannini et al, 2005; Yoon et al, 2016). This study has reached the fourth phase of DILI because the SGOT examination in this study was conducted 2 weeks after the administration of acetaminophen so that the SGOT levels had begun to fall.

Clinically, each treatment group encountered a change in SGOT levels compared to the control group. SGOT levels in the positive control group decreased after being given red cabbage juice at a dose of $0.5 \mathrm{~g} / \mathrm{ml}, 0.7 \mathrm{~g} / \mathrm{ml}$, and $0.9 \mathrm{~g} / \mathrm{ml}$. The decrease in SGOT levels in the group given red cabbage at a dose of $0.5 \mathrm{~g} / \mathrm{ml}$ which had a difference in mean with the positive group of $12.60 \mathrm{IU} / \mathrm{L}$. The decrease in SGOT levels in the group given red cabbage at a dose of 0.7 $\mathrm{g} / \mathrm{ml}$ and $0.9 \mathrm{~g} / \mathrm{ml}$ only experienced a slight decrease from the mean SGOT levels in the positive control group, namely 4.89 and $3.14 \mathrm{UI} / \mathrm{L}$. The decrease in SGOT levels was caused by the presence of anthocyanin content in red cabbage, which has an antioxidant role in the liver. Anthocyanins can bind ROS and increase GSH production, which can convert
NAPQI into non-toxic metabolites and reduce inflammation in hepatocytes, which is characterized by decreased SGOT levels (Wiczkowski, Szawara Nowak and Topolska, 2013). Based on this, it is proven that giving anthocyanins in high concentrations causes low absorption of anthocyanin levels, that is to say in the form of Cyanidine-3 glucoside (Nielsen et al., 2003). A previous study conducted by Bohn and Bouayed (2010) explains that the use of antioxidants at high doses can lead to changes in the effect of antioxidants into prooxidants which increases ROS concentrations, leading to cell damage and cell death (Bohn and Bouayed, 2010). The data in this study verify that administration of high doses of red cabbage juice can cause toxic effects.

Kruskal-Wallis test results of the influence of red cabbage juice on GGT levels have a value of $p=$ $0.053(p>0.05)$ which shows no significant difference in GGT levels among the five groups. This is because the role of GGT itself is as a catalyst in the transfer of $\nu$ glutamyl and facilitates the binding of cysteine to form GSH. Thus, GGT levels reflect an increase in xenobiotic exposure which is metabolized by the glutathionylation pathway, causing GSH depletion, however, GGT will usually come out before ALP with a half-life of 3 days in animals.

\section{CONCLUSIONS}

The administration of red cabbage juice did not affect the levels of SGOT and GGT, while the administration of red cabbage juice had an impact on the levels of ALP with an effective dose of $0.5 \mathrm{~g} / \mathrm{ml}$.

\section{REFERENCES}

Arjinajarn, P., Chueakula, N., Pongchaidecha, A., Jaikumkao, K., Chatsudthipong, V., Mahatheeranont, S., Norkaew, O., Chattipakorn, N., Lungkaphin, A. 2017. 'Anthocyanin-rich Riceberry Bran Extract Attenuates Gentamicin-Induced Hepatotoxicity by Reducing Oxidative Stress, Inflammation and Apoptosis in Rats', Biomedicine and 
Pharmacotherapy. Elsevier Masson SAS, 92, Pp. $412-420$

Aulbach, A. D., Amuzie, C. J. 2017. 'Biomarkers in Nonclinical Drug Development', Elsevier.

Cahaya, N., dan Mutia, R. 2014. 'Evaluasi Obat-Obatan Berpotensi Hepatotoksik pada Pasien Dengan Gangguan Fungsi Hati di Ruang Rawat Inap RSUD Ulin Banjarmasin', Jurnal Pharmascience, I(2), pp. I6-26.

Chambial, S. dan Dwivedi, S. 2013. 'Vitamin C in Disease Prevention and Cure: An Overview', Indian J. Clin. Biochem., 28(4), pp. 3|4-328.

Chughlay, M., Kramer, N., Werfalli, M., Spearman, W., Engel, M., Cohen, K. 2015. 'N -acetylcysteine for Non-Paracetamol Drug-Induced Liver Injury: a Systematic Review Protocol', Systematic Reviews,pp. I-6.

Dalimartha, S. 2008. Atlas Tanaman Obat Indonesia. Cetakan Keempat. Jakarta : Niaga Swadaya.

Damayanti, D. 2008. Buku Pintar Tanaman Obat. Cetakan Pertama. Jakarta : Agromedia Pustaka

Devi, C.B., Basar, G., Devi, N.O., Jamir, S., Nandakishore, T., Singh M.A. . 2014. 'Zinc in Human health', IOSR Journal of Dental and Medical Science, I3 (7), Pp. 18-23.

Draghici, G.A., Alexandra, L.A., Aurica-Breica, B., Nica D., Alda S., Liana, S., Gogoasa I., Gergen I., Despina-Maria, B. (20/3) 'Red Cabbage Millennium's Functional Food', Journal of Horticulture, Forestry and Biothecnology, 17 (4), pp. 52-55.

Dzoyem, J. P., Kuete, V., Eloff, J. N. 2014. 'Biochemical Parameters in Toxicological Studies in Africa, Principles of Method, Data Interpretation and Use in Plant Screening', Elsevier.

El-Motaleb el-Mowafy, M.A. 2012. 'Treatment Effect of Red Cabbage and Cysteine Against Paracetamol Induced', Journal of Applied Science Research, 8(I2), pp. 5852-5859.

Horbowicz, M., Kosson, R., Grzesiuk, A. 2008. 'Anthocyanins of Fruits and Vegetables - Their Occurrence', Analysis, pp. 5-22.

Huang, X., Choi, Y., Im, H., Yarimaga, O., Yoon, E., Kim, H. (2006) 'Aspartate Aminotransferase (AST/GOT) and Alanine Aminotransferase (ALT/GPT) Detection Techniques', Sensors, 6(7), pp. 756-782.
Indrawaty, S., Sosialine, E., Umar, F., Pahlemy, Helsy. 20II Pedoman Interpretasi Data Klinik. Jakarta : Kementerian Kesehatan Republik Indonesia.

Jakobek, L. Seruga, M., Medvidovic-Kosanovic, M., Novak, I. 2007 'Anthocyanin Content and Antioxidant Activity of Various Red Fruit Juices', Deutsche Lebensmittel-Rundschau : Zeitschrift fur Lebensmittelkunde und Lebensmittelrecht, 103(2), pp. 58-64.

Jaeschke, H. 2016. 'Acetaminophen Dose Dependent Drug Hepatotoxicity and Acute Liver Failure', Dig. Dis., 33(4), pp. 464-47I.

Jang, E. S. et al. 2012. 'Effects of Coffee, Smoking, and Alcohol on liver Function Tests: a Comprehensive Cross-Sectional Study', BMC Gastroenterology. BMC Gastroenterology, I2(I), pp. 145.

Kabir, A., Pourshams, A., Khoshnia, M., Malekzadeh, F. 2013. 'Normal Limit for Serum Alanine Aminotransferase Level and Distribution of Metabolic Factors in Old Population of Kalaleh', Iran, Hepatitis Monthly, I 3(I0).

Kingston, J. K. 2008. 'Hematologic and Serum Biochemical Responses to Exercise and Training', Elsevier.

Koenig, G. dan Seneff, S. 2015. 'GammaGlutamyltransferase : A Predictive Biomarker of Cellular Antioxidant Inadequacy and Disease Risk', Disease Markers.

Kozłowska, A. dan Szostak-węgierek, D. 2014. 'Flavonoids - Food Sources and Health Benefits', Rocz. Panstw. Zakl. Hig., 65(2), pp. 79-85.

Legato, M. J. 2004. 'Principles of Gender-Specific Medicine', Elsevier.

Li, D., Wang, P., Luo, Y., Zhao, M., Chen, F. 2017. 'Health Benefits of Anthocyanins and Molecular Mechanisms: Update From Recent Decade', Critical Reviews in Food Science and Nutrition, Taylor \& Francis, 57(8), pp. |729-1741.

Lingga, L. 2010. Cerdas Memilih Sayuran. Cetakan Pertama. Jakarta : Agromedia Pustaka.

Mazaleuskaya, L.L., Sangkuhl, K., Thorn, F.C., FitzGearld, G.A., Altman, R.B., Klein, E.T. 2015. 'PharmGKB Summary: Pathways of Acetaminophen Metabolism at The Therapeuticversus Toxic Doses', Pharmacogenet Genomics, 25(8), pp. 416-426. 
Nair, B., Singh, K.P., Chand, P. 2014. Fundamental of Vegetable Crop Production. Jodhpur : Scientific Publisher.

Pandey, K. B. dan Rizvi, S. I. 2009. 'Plant Polyphenols as Dietary Antioxidants in Human Health and Disease', Oxid. Med. Cell Longev., 2(5), pp. 270278.

Poupon, R. 20I5. 'Liver alkaline phosphatase : a Missing Link Between Choleresis and Biliary Inflammation', Hepatology, 6 I (6), pp. 2080-2090.

Pour Amin Reza, J. 2016. 'Effects of Acetaminophen as a Toxic Drug on the Liver Function in Poultry', Journal of Cancer Prevention \& Current Research, 4(4).

Rokayya, S., Li, Chun-juan., Zhao, Yan., Li, Ying., Sun, Chang-hao. 2013 'Cabbage (Brassica oleracea L . var . capitata) Phytochemicals with Antioxidant and Anti-inflammatory Potential', Asian Pasific Journal of Cancer Prevention, I4(I I), PP. 66576662.

Saraç, F. dan Saygılı, F. 2007. 'Causes of High Bone Alkaline Phosphatase', Biotechnology \& Biotechnological Equipment, Taylor \& Francis, 2I(2), pp. 194-197.

Sayuti, K., Yenrina, R. 20I5. Antioksidan Alami dan Sintetik. Cetakan Pertama. Padang : Andalas University Press.

Schmidt, J., Grober U., Kisters, K. 2015. 'Magnesium in Prevention and Therapy', Nutrients, 7(9), pp. 8199-8226.

Selby, A. 2010. Makanan Berkhasiat. Jakarta : Erlangga. Sepulveda, J. 2013. 'Challenges in Routine Clinical Chemistry Analysis : Protein and Enzimes', New York, Elsevier

Sharma, C. V. and Mehta, V. 20I4. 'Paracetamol: Mechanisms and Updates', Continuing Education in Anaesthesia, Critical Care and Pain, 14(4), Pp. 153-158.

Sharma, U., Pal, D. dan Prasad, R. 2014. 'Alkaline phosphatase : an Overview', Indian Journal of Clinical Biochemistry, 29(3), pp. 269-278.

Smith, G. S., Wolter, G. L., Wolker, R. M. 2013. 'Clinical Pathology in Nonclinical Toxicology Testing', United States, Elsevier.

Tariq, A., Bilal, M., Khan, S., Quratulain, Shahid, M. F., Khan, M. W., Shah, A. R., Naveed, A. K. 201 I. 'Influence of Gender, BMI, and Ethnicity on Serum ALT Levels of Healthy Students of a
Medical School', Journal of Ayub Medical College, Abbottabad: JAMC, 23(I), pp. 70-72.

Vroon, D. H. dan Israili, Z. 1990. 'Alkaline Phosphatase and Gamma Glutamyltransferase, Clinical Methods: The History, Physical, and Laboratory Examinations', pp. 494-496.

Wahyuningsih, H. and Aulia, A. P. 2020. 'Review: Effect of Red Cabbage Juice (Brassica oleracea var. Capitata f. Rubra) on SGPT Level', Borneo Journal of Medical Laboratory Technology, 3(I), Pp. I72-I77. doi: I0.33084/bjmlt.v3il.I79I.

Wang, L., Zhao, Y., Zhuo, Q., Luo, C.L., Deng, A.P., Zhang, Z.C., Zhang, J.L. 2017. 'Characterization and Hepatoprotective Activity of Anthocyanins from Purple Sweet Potato (Ipomoea batatas L. cultivar Eshu No. 8)', Journal of Food and Drug Analysis, Elsevier Ltd, 25(3), pp. 607-618.

Yoon, E., Babar, A., Choudhary, M., Kutner, M., Pyrsopoulus, N. 2016. 'Acetaminophen-Induced Hepatotoxicity: a Comprehensive Update', Journal of Clinical and Translational Hepatology, 4(2), pp. $|3|-\mid 42$.

Yulia, A. dan Wijesiriwardana, A. 2017. 'Extremely High Isolated Maternal Alkaline Phosphatase Serum Concentration -2 Case Reports', 2(4), Pp. I I III3.

Zhang, J., Wang, Z., Liu, X. 2017. 'Characterization Of Acylated Anthocyanins In Red Cabbage Via Comprehensive Two-Dimensional High Performance Liquid Chromatography and HPLC-MS', Journal of Food Processing and Preservation, 4I (2), Pp. I-7. 